\title{
Meat quality of castrated and non-castrated Santa Ines lambs subjected to food restriction
}

\section{Qualidade da carne de cordeiros Santa Inês castrados e não castrados submetidos à restrição alimentar}

\author{
Dayanne Lima de Sousa ${ }^{1}$; Patrícia Guimarães Pimentel ${ }^{2 *}$; \\ Elisabeth Mary Cunha da Silva ${ }^{3}$; Elzânia Sales Pereira ${ }^{4}$; \\ Assis Rubens Montenegro; ; Ana Cláudia Nascimento Campos²; \\ Ivone Yurika Mizubuti ${ }^{6}$; Adrielle Albuquerque dos Santos ${ }^{1}$
}

\begin{abstract}
This study aimed to evaluate the quality of meat of castrated and non-castrated Santa Ines lambs submitted to food restriction. Were used 30 lambs, 15 castrated and 15 non-castrated, about two months of age and average initial body weight of $13.00 \pm 1.49 \mathrm{~kg}$. The lambs were distributed in a completely randomized design in a factorial arrangement $3 \times 2$ (restriction level $\mathrm{x}$ sex class), according to the amount of food provided. The duration of the experiment was determined by the time required for the animals in the one of the groups achieved $28 \mathrm{~kg}$ of body weight. There was interaction between food restriction levels and sex class to the variables intensity of yellow color and $\mathrm{pH}$ in the longissimus lumborum muscle and the shear force in the semimembranosus muscle. In non-castrated animals, the intensity of yellow color was higher in the longissimus lumborum muscle at the level of $30 \%$ of food restriction. There was no significant interaction between food restriction levels and sex class for the quality aspects related to color saturation, color tone, luminosity, red intensity, water holding capacity and cooking losses in longissimus lumborum and semimembranosus muscles. Although food restriction and sex class have influenced the variables related to the quality of meat of the animals evaluated, the mean values are considered acceptable by the literature. The feeding restriction levels and sex class influence some important features of quality of Santa Ines lamb meat.
\end{abstract}

Key words: Animal nutrition. Hair sheep. Ham. Loin. Qualitative parameters.

\section{Resumo}

Objetivou-se avaliar a qualidade da carne de cordeiros Santa Inês castrados e não castrados submetidos à restrição alimentar. Foram utilizados 30 cordeiros, 15 castrados e 15 não castrados, com aproximadamente dois meses de idade e peso corporal inicial médio de $13,00 \pm 1,49 \mathrm{~kg}$. Os cordeiros foram distribuídos em delineamento inteiramente casualizado em arranjo fatorial 3 x 2 (nível de restrição x classe sexual),

\footnotetext{
${ }^{1}$ Discentes do Curso de Mestrado do Programa de Pós-Graduação em Zootecnia, Universidade Federal do Ceará, UFC, Fortaleza, CE, Brasil. E-mail: dayannels@hotmail.com; albuquerque.zootecnia@gmail.com

2 Prof $^{\text {as }}$ Dr $^{\text {as }}$, Departamento de Zootecnia, UFC, Fortaleza, CE, Brasil. E-mail: pgpimentel@hotmail.com; acncampos11@gmail.com

${ }^{3}$ Prof $^{\mathrm{a}} \mathrm{Dr}^{\mathrm{a}}$, Departamento de Tecnologia de Alimentos, UFC, Fortaleza, CE, Brasil. E-mail: elisabeth.cunha@gmail.com

${ }^{4}$ Prof ${ }^{\mathrm{a}} \mathrm{Dr}^{\mathrm{a}}$, Departamento de Zootecnia, UFC, Bolsista de Produtividade do CNPq, UFC, Fortaleza, CE, Brasil. E-mail: elzania@ hotmail.com

${ }^{5}$ Discente do Curso de Doutorado do Programa de Doutorado Integrado em Zootecnia, UFC, Fortaleza, CE, Brasil. E-mail: assismontenegro@yahoo.com.br

${ }^{6}$ Prof $^{\mathrm{a}}$ Dr $^{\mathrm{a}}$, Departamento de Zootecnia, Universidade Estadual de Londrina, UEL, Londrina, PR, Brasil. E-mail: mizubuti@uel.br

* Author for correspondence
} 
de acordo com a quantidade de alimento fornecido. A duração do experimento foi determinada pelo tempo necessário para que a média de peso corporal dos animais de um dos tratamentos atingisse 28 kg. Houve interação entre os níveis de restrição alimentar e as classes sexuais sobre as variáveis de intensidade de cor amarelo e $\mathrm{pH}$ no músculo longissimus lumborum e sobre força de cisalhamento no músculo semimembranosus. Em animais não castrados, a intensidade de cor amarelo foi maior no músculo longissimus lumborum, no nível de $30 \%$ de restrição. Não houve interação significativa entre os níveis de restrição e a classe sexual para os aspectos de qualidade relacionados à saturação de cor, tonalidade da cor, luminosidade, intensidade de vermelho, capacidade de retenção de água e perda de peso por cocção nos músculos longissimus lumborum e semimembranosus. Embora a restrição alimentar e a classe sexual tenham influenciado as variáveis relacionadas à qualidade de carne dos animais avaliados, os valores médios observados são considerados aceitáveis pela literatura. Os níveis de restrição alimentar e a classe sexual influenciam algumas características importantes da qualidade da carne de cordeiros Santa Inês.

Palavras-chave: Lombo. Nutrição animal. Ovinos deslanados. Parâmetros qualitativos. Pernil.

\section{Introduction}

World production of sheep meat has undergone changes, adapting to consumer demands. Currently, the consumer has sought out meat with less fat, e.g., a healthier product, while the producer seeks to optimize production and offer more precocious animals (BONAGURIO, 2001). The Brazilian market is supplied mainly by low-quality lamb meat that generates inhibiting consumption and food taboos among consumers.

The quality of sheep meat is related to factors inherent to the animal, such as nutrition and pre and post slaughter management, including processing and carcasses storage (SILVA; PIRES, 2000; GARCIA et al., 2000). For the producer, quality is an attribute that adds higher price to the product and, consequently, to the consumer, the quality implies satisfaction in consumption (OSÓRIO et al., 2008).

According Sainz (1996), the nutritional status influences the $\mathrm{pH}$, color, tenderness and cooking losses of the meat, which are properties that determine attributes for marketing, as appearance and adaptability to industrial processes.

The lamb is standing out over the decades as a red meat option because of its nutritional value and organoleptic qualities. The study of the qualitative aspects of lamb carcasses becomes important, due to the peculiarities of production systems and used genotypes (SIQUEIRA; FERNANDES, 2000).
In virtue the feeding be one of the major costs and barriers in animal production, food restriction becomes an alternative technique to reduce expenses in sheep production. It is searched a balance between avoiding a decrease in meat quality and enhancing the economic return to the producer (YÃNÉZ et al., 2006; FERNANDES JÚNIOR et al., 2013).

Sex class influences the composition of weight gain, muscle growth and carcass fat deposition, therefore, interferes with the quality attributes, especially the color and meat tenderness (PADUA et al., 2004). According to Kirton (1983), animals of different sex class tend to have different weights and ages to reach the point of slaughter, usually non-castrated animals produce carcass with a higher proportion of muscle and less fat than castrated animals in the same age.

Thus, the aim of this study was to evaluate the meat quality of Santa Ines castrated and noncastrated lambs submitted to food restriction.

\section{Material and Methods}

The study lasted 100 days, extending from October/2013 to January/2014 and it was conducted in digestibility sector of the Department of Animal Science of the Federal University of Ceara (UFC), Fortaleza/Ceara/Brazil. This trial used 30 Santa Ines lambs, with 60 days of age, approximately, and 
average body weight of $13.00 \pm 1.49 \mathrm{~kg}$. Before the trial period, the lambs were identified by numbered earrings, dewormed (Ivermectin) and vaccinated against clostridial infection. Commercial vitamin complexes Potenay® (Fort Dodge, Campinas, Brazil) were provided and ADE, and antibiotic were applied (pentabiotic) in all lambs. Later, the animals were sent to individual stalls with concrete floor covered with wood shavings bedding and equipped with feeding and drinking troughs, where they remained for 15 days for adaptation and the experimental conditions.

The experimental design was completely randomized in a factorial $3 \times 2$ (food restriction levels and sex class), with a total of six treatments. Then, the animals were randomly assigned to treatments according to dietary restriction level (0; 30 and $60 \%$ of food restriction) and sex class (castrated or non-castrated), so that for each level of food restriction had five animals castrated and five animals non-castrated.

In the treatments with food restriction, the amount of food provided was calculated in relation to the animals not submitted to food restriction. The experimental diets were provided to the animals twice a day, at $08 \mathrm{~h} 00$ and $16 \mathrm{~h} 00$, and water ad libitum. The animals in the $0 \%$ food restriction group received diets formulated to produce a mean daily weight gain of $200 \mathrm{~g}$, with forage:concentrate ratio of 60:40 (NRC, 2007).

Before slaughter, animals were weighed and then subjected to an 18-hour fast (no solid food or water) and then weighed again to obtain body weight at slaughter (BWS). At slaughter, lambs were stunned using a cash knocker and killed by exsanguination from jugular vein. Feet, head and other internal components were removed and weighed; then the carcass was weighed, obtaining the hot carcass weight $(\mathrm{HCW})$. Subsequently, the carcasses were transported to a cold chamber at $4^{\circ} \mathrm{C}$ for 24 hours. After the cooling period, the carcasses were weighed to obtain the cold carcass weight (CCW).
The carcass $\mathrm{pH}$ reading was held in the longissimus dorsi muscle 24 hours after slaughter with the aid of a portable digital $\mathrm{pH}$ meter Digimed $\AA$, DM20 model (Digimed, Campo Grande, Brazil), equipped with insertion electrode and resolution of $0.01 \mathrm{pH}$ units (BRESSAN et al., 2001). The left half carcass was subdivided into eight anatomical regions, known as commercial meat cuts (shoulder, leg, fore and rear loin, rib, neck, chest and flank). The rear loin cuts and ham were vacuum packed and stored in a freezer at $-18^{\circ} \mathrm{C}$ for further laboratory analysis.

In the Laboratory of Animal Nutrition, of the Department of Animal Science at Federal University of Ceara, the ingredients (corn ground grain and soybean meal), concentrate feed and Tifton-85 hay were analyzed for dry matter (DM), ash, crude protein (CP) and ether extract (EE), in accordance with the procedures recommended by AOAC (1990). The fiber analysis in neutral detergent fiber (NDF) and acid detergent fiber (ADF) were performed according to Van Soest et al. (1991). The total carbohydrates (TC) were obtained as described by Sniffen et al. (1992), using the following formula $\mathrm{TC}=100-(\% \mathrm{CP}+\% \mathrm{EE}$ $+\%$ Ash) and non-fiber carbohydrates (NFC) were calculated according to the equation proposed by Weiss (1999): NFC $=100-(\%$ NDFap $+\%$ CP $+\% \mathrm{EE}+\%$ Ash), where NDFap is the neutral detergent fiber corrected for ash and protein. The total digestible nutrients (TDN) was calculated according to Weiss (1999), but using the NFC and NDF corrected for ash and protein, through the following equation: $\mathrm{TDN}(\%)=\mathrm{CPd}+\mathrm{NFCd}+$ $\mathrm{NDF} p a d+\mathrm{EEd} \times 2.25 \mathrm{D}$; where: $\mathrm{CPd}=$ digestible crude protein; NDFap = digestible NDFap; NFCd $=$ digestible NFC; and EEd = digestible EE. The chemical composition of the grass Tifton-85 hay, the ingredients of the concentrate feed, as well as the experimental diet is presented in Tables 1 and 2 , respectively. 
Table 1. Chemical composition of the ration ingredients in $\mathrm{g} \mathrm{kgMS}^{-1}$.

\begin{tabular}{lcccc}
\hline Nutrients & Tifton-85 hay & Corn ground grain & Soybean meal & Concentrated \\
\hline Dry matter & 929.58 & 900.57 & 901.22 & 897.51 \\
Crude Protein & 110.61 & 77.01 & 532.05 & 291.10 \\
Ash & 66.95 & 15.04 & 70.34 & 55.10 \\
Ether extract & 15.32 & 66.30 & 11.84 & 32.11 \\
$\mathrm{NDF}^{1}$ & 707.70 & 152.95 & 193.86 & 168.22 \\
$\mathrm{NDFap}^{2}$ & 673.52 & 141.28 & 128.03 & 123.37 \\
$\mathrm{ADF}^{3}$ & 352.97 & 25.96 & 85.96 & 57.76 \\
$\mathrm{TCH}^{4}$ & 807.12 & 841.65 & 385.77 & 621.68 \\
$\mathrm{NFC}^{5}$ & 133.60 & 700.37 & 257.74 & 520.71 \\
\hline
\end{tabular}

${ }^{1}$ Neutral detergent fiber, ${ }^{2}$ Neutral detergent fiber correct for ash and protein, ${ }^{3}$ Acid detergent fiber, ${ }^{4}$ Total carbohydrates, ${ }^{5}$ Non-fiber carbohydrates.

Table 2. Percentage and chemical composition of the experimental diet.

\begin{tabular}{|c|c|}
\hline \multicolumn{2}{|l|}{ Ingredients (\% Natural matter) } \\
\hline Tifton- 85 hay & 60 \\
\hline Concentrate $^{1}$ & 40 \\
\hline Corn ground grain & 20.07 \\
\hline Soybean meal & 19.23 \\
\hline Limestone & 0.19 \\
\hline Dicalcium phosphate & 0.41 \\
\hline Sodium chloride & 0.07 \\
\hline Premix $^{2}$ & 0.03 \\
\hline \multicolumn{2}{|l|}{ Chemical composition $\left(\mathrm{g} \mathrm{kgMS}^{-1}\right)$} \\
\hline Dry matter & 918.10 \\
\hline Crude protein & 184.14 \\
\hline Ash & 56.53 \\
\hline Ether extract & 24.60 \\
\hline $\mathrm{NDF}^{3}$ & 492.60 \\
\hline NDFap $^{4}$ & 456.49 \\
\hline $\mathrm{ADF}^{5}$ & 233.52 \\
\hline $\mathrm{TC}^{6}$ & 727.37 \\
\hline $\mathrm{NFC}^{7}$ & 270.29 \\
\hline $\mathrm{TDN}^{8}$ & 558.02 \\
\hline \multicolumn{2}{|c|}{$\begin{array}{l}{ }^{1} \text { Centesimal composition in relative to the total } \\
\text { feed, }{ }^{2} \text { Composition: Ca } 7.5 \% \text {, P } 3 \% \text {; Fe } 16.500 \mathrm{ppm}, \mathrm{Mn} 9.750 \\
\text { ppm, Zn } 35.000 \mathrm{ppm}, \mathrm{I} 1.000 \mathrm{ppm} \text {, Se } 225 \mathrm{ppm} \text {, Co } 1.000 \mathrm{ppm} \text {, } \\
{ }^{3} \mathrm{Neutral} \text { detergent fiber, }{ }^{4} \text { Neutral detergent fiber corrected for } \\
\text { ash and protein, }{ }^{5} \text { Acid detergent fiber, }{ }^{6} \text { Total carbohydrates, } \\
{ }^{7} \text { Non-fiber carbohydrates, }{ }^{8} \text { Total digestible nutrients. }\end{array}$} \\
\hline
\end{tabular}

Samples of longissimus lumborum muscle and the semimembranosus muscle were analyzed in the Meat and Fish Laboratory of the Department of Food Technology of the Agricultural Science Center at Federal University of Ceara. After thawing for 24 hours at $10^{\circ} \mathrm{C}$, with scalpel and knife, was separated from each piece, a muscle representative sample of the loin (longissimus lumborum) and leg (semimembranosus) for determining the following meat quality traits: color, $\mathrm{pH}$, water holding capacity (WHC), cooking losses (CL) and shear force (SF). The color measurement was performed at the Quality Control Laboratory of Department of Food Technology of the Agricultural Sciences Center at Federal University of Ceara, using the colorimeter Minolta ${ }^{\circledR}$ CR400 (Minolta Co., Osaka, Japan), measuring L* (luminosity), a* (red color intensity) and $b^{*}$ (yellow color intensity) of the CIELAB system (Commissiom Internationale de l'Eclairage), $\mathrm{c}^{*}$ (color saturation) and $\mathrm{H}$ (color tone). The packages were opened and the samples of the longissimus lumborum and semimembranosus muscles were exposed to the atmospheric oxygen for 30 minutes to allow the superficial oxygenation of myoglobin. Three measurements were made at three different locations of the muscles, observing the average values of $\mathrm{L}^{*}, \mathrm{a}^{*}, \mathrm{~b}^{*}, *$ and $\mathrm{H}$.

For determination of the meat $\mathrm{pH}$ of the longissimus lumborum and semimembranosus muscles, samples were ground and weighed (10 $\mathrm{g}$ each), in triplicate and placed into beakers. 
Then, $10 \mathrm{~g}$ of distilled water were added and homogenized with a glass rod for 1 minute and left to stand at room temperature for approximately 10 minutes. The meat $\mathrm{pH}$ was measured with the aid of a digital $\mathrm{pH}$ meter previously calibrated (CANAQUE; SANUDO, 2000).

The WHC was evaluated by mincing meat samples of each muscle, then $5 \mathrm{~g}$ of the samples were weighed in triplicate, distributed in test tubes and added $8 \mathrm{~mL}$ of $\mathrm{NaCl}$ solution $(0.6 \mathrm{M})$. Samples were homogenized for one minute and immersed in ice for 30 minutes, then agitated for one minute and transferred into a Beckman J2-21 centrifuge and went through centrifugation process for 15 minutes at $10.000 \mathrm{rpm}$ and $4^{\circ} \mathrm{C}$. The supernatant samples were transferred to $10 \mathrm{~mL}$ beakers for volume measurement, and the volume difference obtained expressed per $100 \mathrm{~g}$ of sample (PARDI et al., 1993).

To evaluate the CL were removed three rectangular segments of meat with $2.5 \mathrm{~cm}$ thick and $5 \mathrm{~cm}$ length of each muscle. The samples were weighed and placed in plastic bags, vacuum packed and conducted to the bath at $85^{\circ} \mathrm{C}$ during 25 minutes. Subsequently, the samples were cooled in running water, remaining in the closed bags (LIU et al., 2004). Then were removed from the bags and weighed again when the CL was calculated as the following equation: liquid lost $\%=((\mathrm{Mo}-\mathrm{Mf})$ $\mathrm{x} 100) / \mathrm{Mo})$, where Mo = cooked meat mass and Mf $=$ mass of fresh meat.

To evaluate the SF, six symmetrical cylinders of cooked samples with $1.6 \mathrm{~cm}$ diameter were taken from each muscle. The cylinders were removed in the direction of the fiber, avoiding fat and fascia. The shear force was measured with a TA-XT2® texturometer (Stable Micro System Surrey, United Kingdom), fitted with a Warner Bratzler blade, operating at a speed of $5 \mathrm{~mm} / \mathrm{s}$ at a distance of 25 $\mathrm{mm}$.

The carcass $\mathrm{pH}$ measures: $\mathrm{L}^{*}, \mathrm{a}^{*}, \mathrm{~b}^{*}, \mathrm{C}^{*}$ and $\mathrm{H}, \mathrm{pH}, \mathrm{WHC}, \mathrm{CL}, \mathrm{SF}$ of longissimus lumborum and semimembranosus muscles were submitted to analysis of variance (PROC GLM) using the Analysis System Statistics - SAS (SAS, 2003). Data were expressed as mean and standard deviation and compared by Tukey test using 0.05 significance level.

\section{Results and Discussion}

There was interaction between food restriction levels and sex class for yellow color intensity (b*) in the muscle longissimus lumborum $(\mathrm{P}<0.05$; Table 3). Non-castrated animals showed yellow color intensity greater in the $30 \%$ level of food restriction $(\mathrm{P}<0.05)$. Significant difference was observed $(\mathrm{P}<0.05)$ between sex class in the $0 \%$ food restriction level in which castrated animals presented higher values than the non-castrated for intensity of yellow color.

Table 3. Yellow intensity ( $\mathrm{b}^{*}$ ) of the muscle longissimus lumborum of Santa Ines lambs of different sex class submitted to food restriction.

\begin{tabular}{lccc}
\hline \multirow{2}{*}{ Sex class } & \multicolumn{3}{c}{ Level of restriction } \\
\cline { 2 - 4 } & $0 \%$ & $30 \%$ & $60 \%$ \\
\hline Non-castrated & $8.34^{\mathrm{bB}}$ & $9.99^{\mathrm{a}}$ & $8.45^{\mathrm{b}}$ \\
Castrated & $10.16^{\mathrm{A}}$ & 9.24 & 9.81 \\
\hline
\end{tabular}

${ }^{\mathrm{a}-\mathrm{b}}$ Means followed by lowercase letters in the line differ by Tukey test $(\mathrm{P}<0.05)$.

A-B Means followed by capital letters in the column differ by Tukey test $(\mathrm{P}<0.05)$.

The results observed in the yellow intensity were similar to those found in the literature for Santa Ines sheep, which indicate values for yellow intensity $\left(b^{*}\right)$ ranging from 3.38 to 11.10 (SAÑUDO et al., 2000; WARRIS, 2003; PRADO, 1999). According to Pinheiro et al. (2009), the intensity of yellow color is more significant in the color of the fat, therefore justifies the castrated animals present higher intensity of yellow color. The muscle color characteristics can also be 
influenced by the species, sex, pre-slaughter stress, age of the animal and post-slaughter treatment (BABIKER et al., 1990; SHACKELFORD et al., 1992; APPLE et al., 1995).
There was no significant interaction between food restriction levels and sex class on the quality aspects related to color saturation $\left(\mathrm{c}^{*}\right)$, color tone $(\mathrm{H})$, luminosity $\left(\mathrm{L}^{*}\right)$ and red color intensity $\left(\mathrm{a}^{*}\right)$ in the longissimus lumborum muscle (Table 4).

Table 4. Color saturation $\left(\mathrm{c}^{*}\right)$, color tone $(\mathrm{H})$, luminosity $\left(\mathrm{L}^{*}\right)$ and red color intensity $\left(\mathrm{a}^{*}\right)$ of the longissimus lumborum muscle of Santa Ines lambs of different sex class submitted to food restriction.

\begin{tabular}{lccccc}
\hline \multirow{2}{*}{ Variable } & \multicolumn{2}{c}{ Sex class } & \multicolumn{3}{c}{ Restriction level } \\
\cline { 2 - 6 } & Non-castrated & Castrated & $0 \%$ & $30 \%$ & $60 \%$ \\
\hline $\mathrm{c}^{*}$ & 14.79 & 15.21 & 15.33 & 15.30 & 14.43 \\
$\mathrm{H}$ & 40.56 & 40.13 & 41.80 & 39.14 & 40.26 \\
$\mathrm{~L}^{*}$ & 42.76 & 45.89 & 41.29 & 45.43 & 45.80 \\
$\mathrm{a}^{*}$ & 11.12 & 11.63 & 11.16 & 11.83 & 11.09 \\
\hline
\end{tabular}

Pinheiro et al. (2009), evaluating the meat quality in the longissimus lumborum muscle in castrated adult male sheep, observed values of $\mathrm{L}^{*}$ and $\mathrm{a}^{*}$ of 34.36 and 19.48 , respectively, differing from those found in this study.

There was no significant interaction between food restriction levels and sex class on the quality aspects related to color saturation $\left(\mathrm{c}^{*}\right)$, color tone $(\mathrm{H})$, luminosity $\left(\mathrm{L}^{*}\right)$, red intensity $\left(\mathrm{a}^{*}\right)$ and yellow intensity $\left(\mathrm{b}^{*}\right)$ in the semimembranosus muscle (Table 5).
Significant differences were found $(\mathrm{P}<0.05)$ to the food restriction level on color saturation $\left(\mathrm{c}^{*}\right)$ and red color intensity $\left(\mathrm{a}^{*}\right)$ and regarding the sex class to yellow color intensity $\left(b^{*}\right)$. The color saturation results $\left(\mathrm{c}^{*}\right)$ and red intensity $\left(\mathrm{a}^{*}\right)$ of the semimembranosus muscle were higher in animals with $30 \%$ food restriction level in relation to animals fed ad libitum, but did not differ from animals with $60 \%$ food restriction level. Regarding the yellow intensity $\left(b^{*}\right)$, the noncastrated animals showed higher values than the castrated.

Table 5. Color saturation $\left(\mathrm{c}^{*}\right)$, color tone $(\mathrm{H})$, luminosity $\left(\mathrm{L}^{*}\right)$, red intensity $\left(\mathrm{a}^{*}\right)$ and yellow intensity $\left(\mathrm{b}^{*}\right)$ of the semimembranosus muscle of Santa Ines lambs of different sex class submitted to food restriction.

\begin{tabular}{lccccc}
\hline \multirow{2}{*}{ Variable } & \multicolumn{3}{c}{ Sex class } & \multicolumn{3}{c}{ Restriction level } \\
\cline { 2 - 6 } & Non-castrated & Castrated & $0 \%$ & $30 \%$ & $60 \%$ \\
\hline $\mathrm{c}^{*}$ & 21.47 & 20.92 & $19.80^{\mathrm{b}}$ & $22.60^{\mathrm{a}}$ & $20.91^{\mathrm{ab}}$ \\
$\mathrm{H}$ & 23.96 & 19.98 & 25.71 & 19.28 & 21.50 \\
$\mathrm{~L}^{*}$ & 44.67 & 47.46 & 41.31 & 46.85 & 49.42 \\
$\mathrm{a}^{*}$ & 19.01 & 19.32 & $17.00^{\mathrm{b}}$ & $20.86^{\mathrm{a}}$ & $19.41^{\mathrm{ab}}$ \\
$\mathrm{b}^{*}$ & $7.95^{\mathrm{A}}$ & $7.00^{\mathrm{B}}$ & 7.52 & 7.35 & 7.61 \\
\hline
\end{tabular}

A, B Means followed by different capital letters in the line are different from each other for sex classes by Tukey test $(\mathrm{P}<0.05)$.

${ }^{\mathrm{a}, \mathrm{b}}$ Means followed by different lowercase letters in the line are different from each other for restriction levels by Tukey test $(\mathrm{P}<0.05)$. 
Sañudo et al. (1996) evaluated the influence of the carcass weight on the quality characteristics of Aragon sheep meat and found values of $\mathrm{a}^{*}=13.94$ and 16.95 and $b^{*}=5.90$ and 6.86 in carcasses weighing of 8.07 and $13.42 \mathrm{~kg}$, respectively. These researchers found that the heavier carcasses showed darker meat, indicating that the $\mathrm{L}^{*}, \mathrm{a}^{*}, \mathrm{~b}^{*}$ may be responsive to the weight, breed and sex class. Lambs with high amount of fat may have more dark meat because fat implies the loss of capillary permeability, leading to difficulties in the oxygen transfer of the muscle fiber, increasing the need of myoglobin for the oxygen storage, causing increase on the red intensity $\left(a^{*}\right)$ and decreasing the luminosity level (BONAGURIO, 2001). A fact not represented in this study, because the animals fed ad libitum presented results with less red intensity and less luminosity.

There was interaction between food restriction levels and sex classes on the $\mathrm{pH}$ in the longissimus lumborum muscle (Table 6). There was no difference between sex classes for this variable $(\mathrm{P}>0.05)$. However, the castrated animals and subjected to $60 \%$ of food restriction showed $\mathrm{pH}$ value higher than those with $30 \%$ food restriction level, not differing from animals fed ad libitum $(\mathrm{P}<0.05)$.

Table 6. Mean values of $\mathrm{pH}$ in the longissimus lumborum muscle of Santa Ines lambs of different sex class submitted to food restriction.

\begin{tabular}{lccl}
\hline \multirow{2}{*}{ Sex class } & \multicolumn{3}{c}{ Restriction level } \\
\cline { 2 - 4 } & $0 \%$ & $30 \%$ & $60 \%$ \\
\hline Non-castrated & 5.75 & 5.74 & 5.72 \\
Castrated & $5.73^{\mathrm{ab}}$ & $5.63^{\mathrm{b}}$ & $5.84^{\mathrm{a}}$ \\
\hline
\end{tabular}

${ }^{a-b}$ Means followed by lowercase letters in line differ by Tukey test $(\mathrm{P}<0.05)$.

According Bonagurio (2001), sex classes, as well the breed has little influence on the ovine meat $\mathrm{pH}$. This can be confirmed, since there were no differences between the sex classes in this study. However, according to that researcher, non-castrated males may have higher meat $\mathrm{pH}$ due to the agitated temperament, releasing greater amounts of catecholamines before slaughter, resulting in lower reserve of muscle glycogen.

According to Luciano et al. (2012), higher final $\mathrm{pH}$ values on sheep meat can be found, because this variable is associated with low nutrient levels or energy costs, which is related to pasture-based feeding system, resulting in lower concentration of glycogen in muscle. A pH evaluation is an acceptable measure for estimating the quality of meat as the final product of the muscle meat transformation process, and the $\mathrm{pH}$ average values found in this study are within the expected normal range between 5.5 and 5.8 (FORREST et al., 1979).

Regarding the SF, it was observed interaction between food restriction level and sex classes $(\mathrm{P}<0.05 ;$ Table 7). There was a significant difference $(\mathrm{P}<0.05) \quad$ compared to the $30 \%$ restriction level. Meat of non-castrated animals showed lower SF if compared to the castrated animals. Within sex class, non-castrated animals with $60 \%$ food restriction showed meat with greater $\mathrm{SF}$ in relation to meat from animals subjected to other levels $(\mathrm{P}<0.05)$. The $\mathrm{SF}$ was higher in castrated animal meat submitted to $30 \%$ of food restriction.

Table 7. Shear force (kgf) of the longissimus lumborum muscle of Santa Ines lambs of different sex class submitted to food restriction.

\begin{tabular}{lccc}
\hline \multirow{2}{*}{ Sex class } & \multicolumn{3}{c}{ Restriction level } \\
\cline { 2 - 4 } & $0 \%$ & $30 \%$ & $60 \%$ \\
\hline Non-castrated & $1.42^{\mathrm{b}}$ & $1.57^{\mathrm{bB}}$ & $1.93^{\mathrm{a}}$ \\
Castrated & $1.29^{\mathrm{b}}$ & $2.18^{\mathrm{aA}}$ & $1.52^{\mathrm{b}}$ \\
\hline
\end{tabular}

a-b Means followed by lowercase letters in line differ by Tukey test $(\mathrm{P}<0.05)$.

A-B Means followed by capital letters in the column differ by Tukey test $(\mathrm{P}<0.05)$. 
The tender of the meat can be influenced by sex class, and it is associated with muscle formation and deposition of fat in animals. In general, noncastrated animal has tougher meat than castrated lambs and females, and castrated animals presented intermediate values between non-castrated and females (BONAGURIO, 2001). This was not featured in the study, since the $30 \%$ food restriction level castrated animals showed higher SF meat than non-castrated.

Kemp et al. (1972), working with 30 noncastrated and 30 castrated lambs, from crossing Hampshire sheep and crossbred sheep, allocated in one of the slaughter weight groups, 36, 45 and $54 \mathrm{~kg}$ found that SF decreases with increasing weight in both sexual class. This finding was not observed in animals with 30\% food restriction and castrated, which showed higher SF meat for the animals subjected to other levels of restriction. However, similar results were found by the researcher and it was observed in non-castrated animals subjected to $60 \%$ food restriction; in other words, it presented lower weight, which showed higher SF meat thus less tenderness.

Prado (1999), evaluating the aspects of meat quality of lambs Santa Ines and Bergamacia slaughtered at different weights, found values around 2.30 to $3.20 \mathrm{kgf}$ for the shear force of the meat of Santa Ines and Zapata et al. (2000), assessing the quality of the Brazilian northeastern sheep meat, found SF value of $4.63 \mathrm{kgf}$, both results higher than described in this study. Sañudo et al. (1996) evaluated the influence of weight on the quality of meat in sheep of the Churra, Castellana, Manchego and Awassi breeds and found SF results of $3.65,4.04,4.33$ and $3.43 \mathrm{kgf}$, respectively.

According to the classification by Cezar and Sousa (2007), the meat of Santa Ines lambs of this study was classified as tender as could not resist a pressure less than $2.27 \mathrm{kgf}$. Thus, the results found in this study showed that the meat tenderness in Santa Ines sheep can be attractive to the consumer.

There was no significant interaction between the restriction levels and sex classes for the quality aspects related to the WHC and CL for muscle longissimus lumborum ( $\mathrm{P}>0.05$; Table 8$)$.

Table 8. Water holding capacity (WHC) and cooking losses (CL) of the muscle longissimus lumborum of Santa Ines lambs of different sex class submitted to food restriction.

\begin{tabular}{lccccc}
\hline \multirow{2}{*}{ Variable } & \multicolumn{2}{c}{ Sex class } & \multicolumn{3}{c}{ Restriction level } \\
\cline { 2 - 6 } & Non-castrated & Castrated & $0 \%$ & $30 \%$ & $60 \%$ \\
\hline WHC (\%) & 75.89 & 80.98 & 77.52 & 80.00 & 77.49 \\
CL $(\%)$ & 32.55 & 33.62 & 32.84 & 32.93 & 33.40 \\
\hline
\end{tabular}

Pinheiro et al. (2009) evaluated the quality of meat in the longissimus lumborum muscle in castrated adult males and observed WHC and CL values of 56.43 and 39.33 , respectively. The proximity to the WHC values found probably occurred because of the $\mathrm{pH}$ observed have been presented within the expected normal range, and according to Lanza et al. (2003), changes in $\mathrm{pH}$ have influence in the water holding capacity variations of the red meat. There was no significant interaction between the restriction levels and sex classes on the quality aspects related to $\mathrm{pH}, \mathrm{WHC}, \mathrm{CL}$ and $\mathrm{SF}$ in the semimembranosus muscle ( $\mathrm{P}>0.05$; Table 9). For CL in semimembranosus muscle, significant differences were found $(\mathrm{P}<0.05)$ between castrated and non-castrated. The CL was influenced with $60 \%$ food restriction level, with higher values when compared to animals in the 0 and $30 \%$ restriction. 
Table 9. Mean values to $\mathrm{pH}$, water holding capacity (WHC), cooking losses (CL) and shear force (SF) of the semimembranosus in the semimembranosus muscle of Santa Ines lambs of different sex class submitted to food restriction.

\begin{tabular}{lccccc}
\hline \multirow{2}{*}{ Variable } & \multicolumn{2}{c}{ Sex class } & \multicolumn{3}{c}{ Restriction level } \\
\cline { 2 - 6 } & Non-castrated & Castrated & $0 \%$ & $30 \%$ & $60 \%$ \\
\hline $\mathrm{pH}$ & 5.63 & 5.67 & 5.65 & 5.62 & 5.69 \\
$\mathrm{WHC}(\%)$ & 82.05 & 84.48 & 78.08 & 83.74 & 87.34 \\
$\mathrm{CL}(\%)$ & $39.70^{\mathrm{B}}$ & $41.67^{\mathrm{A}}$ & $39.62^{\mathrm{b}}$ & $39.51^{\mathrm{b}}$ & $42.72^{\mathrm{a}}$ \\
$\mathrm{SF}(\mathrm{kgf})$ & 1.96 & 2.05 & 1.58 & 2.21 & 2.17 \\
\hline
\end{tabular}

${ }^{\mathrm{A}, \mathrm{B}}$ Means followed by different capital letters in the line are different from each other for sex class by Tukey test $(\mathrm{P}<0.05)$.

${ }^{\mathrm{a}, \mathrm{b}}$ Means followed by different lowercase letters in the line are different from each other for restriction levels by Tukey test $(\mathrm{P}<0.05)$.

The $\mathrm{pH}$ meat values in this study were similar to those found by Bonagurio et al. (2003) that working with pure sheep Santa Ines and crossbred Texel on different slaughter weights, found $\mathrm{pH}$ values in the longissimus dorsi muscle of 5.76 and semimembranosus of 5.69 .

Castrated animals tend to accumulate a higher percentage of subcutaneous fat avoiding the shortening of muscle fibers during the cooking and cooling, thereby reducing the cooking losses (PRADO et al., 2009). CL results of this experiment differed from the Prado et al. (2009), as castrated animals showed CL values higher than non-castrated (41.67\% and $39.70 \%$, respectively). The cooking process of the meat dissolves part of the solid fat, releasing certain amount of fat, so it can be inferred that the castrated animals possibly showed higher fat content and consequently higher CL. However, in relation to the food restriction levels, the greater CL value was found in animals with $60 \%$ food restriction level, or in animal with lower weight and probably lower fat content in the meat.

\section{Conclusions}

The food restriction levels and sex class influence the yellow intensity, color saturation, red intensity, $\mathrm{pH}$ and cooking losses, important quality characteristics of Santa Ines lamb meat, however they remain in quality standards recommended by the literature.

\section{Acknowledgements}

The authors wish to thank the CNPq (National Counsel of Technological and Scientific Development) for financial support (Proc. 304666/2012). The first author benefited from a grant from The FUNCAP (Cearense Foundation for the Support of Scientific and Technological Development).

\section{References}

APPLE, J. K.; DIKEMAN, M. E.; MINTON, J. E.; MCMURPHY, R. M.; FEDDE, M. R.; LEITH, D. E.; UNRUH, J. A. Effects of restrain and isolation stress and epidural blockade on endocrine and blood metabolite status, muscle glycogen metabolism, and indice of darckcutting longissimus muscle of Sheep. Journal of Animal Science, Champaign, v. 73, n. 8, p. 2295-2307, 1995.

ASSOCIATION OF OFFICIAL ANALYTICAL CHEMISTRY - AOAC. Official methods of analysis. $15^{\text {th }}$ ed. Arlington: AOAC International, 1990. $1117 \mathrm{p}$.

BABIKER, S. A.; EL KHIDER, I. A.; SHAFIE, S. A. Chemical composition and quality attributes of goat meat and lamb. Meat Science, Barking, v. 28, n. 4, p. 273-277, 1990.

BONAGURIO, S. Qualidade da carne de cordeiros Santa Inês puros e mestiços com Texel abatidos com diferentes pesos. 2001. Dissertação (Mestrado em Zootecnia) Universidade Federal de Lavras, Lavras.

BONAGURIO, S.; PÉREZ, J. R. O.; GARCIA, I. F. F.; BRESSAN, M. C.; LEMOS, A. L. S. C. Qualidade da carne de cordeiros Santa Inês puros e mestiços com Texel abatidos com diferentes pesos. Revista Brasileira de Zootecnia, Viçosa, MG, v. 32, n. 6, p. 1981-1991, 2003. Suplemento 2. 
BRESSAN, M. C.; PRADO, O. V.; PÉREZ, J. R. O.; LEMOS, A. L. S. C.; BONAGURIO, S. Efeito do peso ao abate de cordeiros Santa Inês e Bergamácia sobre as características físico-químicas da carne. Ciência e Tecnologia de Alimentos, Campinas, v. 21, n. 3, p. 293303, 2001.

CANAQUE, V.; SANUDO, C. Metodologia para el estúdio de La calidad canal e de La carne de ruminantes. Madrid: Instituto Nacional de Investigación y Tecnologia y Alimenticia, 2000. $255 \mathrm{p}$.

CEZAR, M. F.; SOUSA, W. H. Carcaças ovinas e caprinas: obtenção, avaliação, classificação. Uberaba: Ed. Agropecuária Tropical, 2007. 147 p.

FERNANDES JÚNIOR, F.; RIBEIRO, E. L. A.; MIZUBUTI, I. Y.; SILVA, L. D. F.; BARBOSA, M. A. A. F.; PRADO, O. P. P.; PEREIRA, E. S.; PIMENTEL, P. G.; CONSTANTINO, C. Características de carcaça e qualidade da carne de cordeiros Santa Inês alimentados com torta de girassol em substituição ao farelo de algodão. Semina: Ciências Agrárias, Londrina, v. 34, n. 6, p. 3999-4014, 2013. Suplemento 2.

FORREST, J. C.; ABERLE, E. D.; HEDRICK, H. B. Fundamentos de ciencia de la carne. Zaragoza: Acribia, 1979. $342 \mathrm{p}$.

GARCIA, I. F. F.; GARCIA, I. F. F.; PÉREZ, J. R. O.; TEIXEIRA, J. C.; BARBOSA, C. M. P. Desempenho de cordeiros Texel x Bergamácia, Texel x Santa Inês e Santa Inês puros, terminados em confinamento, alimentados com casca de café como parte da dieta. Revista Brasileira de Zootecnia, Viçosa, MG, v. 29, n. 2, p. 564-572, 2000.

KEMP, J. D.; SHELLEY, J. M.; ELY, D. G.; MOODY, W. G. Effects of castration and slaughter weight on fatness, cooking losses and palability of lamb. Journal of Animal Science, Champaign, v. 34, n. 4, p. 560-562, 1972.

KIRTON, A. H. The effect of farm management practices on lamb carcass composition and quality. Wool technology and sheep breeding, Sydney, v. $31 \mathrm{n}$. 1 p. 27-33, 1983.

LANZA, M.; BELLA, M.; PRIOLO, A.; FASONE, V. Peas (Pisum sativum L.) as an alternative protein source in lamb diets: growth performances, and carcass and meat quality. Small Ruminant Research, Amsterdam, v. 47, n. 1, p. 63-68, 2003.

LIU, Y.; LYON, B. G.; WINDHAM, W. R.; LYON, C. E.; SAVAGE, E. M. Principal component analysis of physical, color, and sensory characteristics of chicken breasts deboned at two, four, six, and twenty-four hours postmortem. Poultry Science, Oxford, v. 83, n. 1, p. 101108, 2004.
LUCIANO, G.; BIONDI, L.; PAGANO, R. I.; SCERRA, M.; VASTA, V.; LOPEZ ANDRES, P.; VALENTI, B.; LANZA, M.; PRIOLO, A.; AVONDO, M. The restriction of grazing duration does not compromise lamb meat colour and oxidative stability. Meat Science, Barking, v. 92, n. 1, p. 30-35, 2012.

NATIONAL RESEARCH COUNCIL - NRC. Nutrient requirements of small ruminants: sheep, goats, cervids, and new world camelids. Washington, D.C.: The National Academies Press, 2007. 347 p.

OSÓRIO, M. T.; OSÓRIO, J. C. S.; SILVA SOBRINHO, A. G. Avaliação instrumental da carne ovina. In: SILVA SOBRINHO, A. G.; SAÑUDO, C. A.; OSÓRIO, J. C. S.; ARRIBAS, M. M. C.; OSÓRIO, M. T. M. Produção da carne ovina. Jaboticabal: Funep, 2008. p. 129-146.

PÁDUA, J. T.; MAGNABOSCO, C. U.; SAINZ, R. D.; MIYAGI, E. S.; PRADO, C. S.; RESTLE, J.; RESENDE, L. S. Genótipo e condição sexual no desempenho e nas características de carcaça de bovinos de corte super jovens. Revista Brasileira de Zootecnia, Viçosa, MG, v. 33, n. 6, p. 2330-2342, 2004. Suplemento 3.

PARDI, M. C.; SANTOS, I. F.; SOUZA, E. R.; PARDI, H. S. Ciência, higiene e tecnologia da carne. 2. ed. Goiânia: UFG, 1993. 623 p.

PINHEIRO, R. S. B.; SILVA SOBRINHO, A. G.; SOUZA, H. B. A.; YAMAMOTO, S. M. Qualidade de carnes provenientes de cortes da carcaça de cordeiros e de ovinos adultos. Revista Brasileira de Zootecnia, Viçosa, MG, v. 38, n. 9, p. 1790-1796, 2009.

PRADO, I. N.; OLIVEIRA, A. N.; ROTTA, P. P.; PEROTTO, D.; PRADO, R. M.; SILVA, R. R.; SOUZA, N. E.; MOLETTA, J. L. Chemical and fatty acid composition of Longissimus muscle of crossbred bulls finished in feedlot. Asian Australasian Journal of Animal Science, Seoul, v. 22, n. 7, p. 1054-1059, 2009.

PRADO, O. V. Qualidade da carne de cordeiros Santa Inês e Bergamácia abatidos com diferentes pesos. 1999. Dissertação (Mestrado em Zootecnia) - Universidade Federal de Lavras, Lavras.

SAINZ, R. D. Qualidade de carcaças e de carnes de ovinos e caprinos. In: REUNIÃO ANUAL DA SOCIEDADE BRASILEIRA DE ZOOTECNIA, 1996, Fortaleza. Anais... Fortaleza: SBZ, 1996. p. 3-14.

SAÑUDO, C.; ENSER, M. E.; CAMPO, M. M.; NUTE, G. R.; MARÍA, G.; SIERRA, I.; WOOD, J. D. Fatty acid composition and sensory characteristics of lamb carcasses from Britain and Spain. Meat Science, Barking, v. 54 , n. 4 , p. $339-346,2000$. 
SAÑUDO, C.; SANTOLARIA, M. P.; MARÍA, G.; OSORIO, M.; SIERRA, I. Influence of carcass weight on instrumental and sensory lamb meat quality in intensive production systems. Meat Science, Barking, v. 42, n. 2, p. 195-202, 1996.

STATISTICAL ANALYSIS SYSTEM INSTITUTE SAS INSTITUTE INC. Statistical analysis system for Windows, Release 9.1. Cary: SAS Institute, 2003.

SHACKELFORD, S. D.; PURSER, D. E.; SMITH, G. C.; GRIFFIN, C. L.; STIFFLER, D. M.; SAVELL, J. W. Lean color characteristics of bullock and steer beef. Journal of Animal Science, Champaign, v. 70, n. 2, p. 465-469, 1992.

SILVA, L. F.; PIRES, C. C. Avaliações quantitativas e predição das proporções de osso, músculo e gordura da carcaça em ovinos. Revista Brasileira de Zootecnia, Viçosa, MG, v. 29, n. 4, p. 1253-1260, 2000.

SIQUEIRA, E. R.; FERNANDES, S. Efeito do genótipo sobre as medidas objetivas e subjetivas da carcaça de cordeiros terminados em confinamento. Revista Brasileira de Zootecnia, Viçosa, MG, v. 29, n. 1, p. 15163598, 2000.

SNIFFEN, C. J.; O'CONNOR, J. D.; VAN SOEST, P. J.; FOX, D. G.; RUSSELL, J. B. A net carbohydrate and protein system for evaluating cattle diets: II. Carbohydrate and protein availability. Journal of Animal Science, Champaign, v. 70, n. 10, p. 3562-3577, 1992.
VAN SOEST, P. J.; ROBERTSON, J. B.; LEWIS, B. A. Symposium: carbohydrate methodology, metabolism, and nutritional implications in dairy cattle. Journal of Dairy Science, Madison, v. 74, n. 10, p. 3583-3597, 1991.

WARRIS, P. D. Ciencia de la carne. Zaragoza: Acribia, 2003. 309 p.

WEISS, W. P. Energy prediction equations for ruminant feeds. In: CORNELL NUTRITION CONFERENCE FOR FEED MANUFACTURERS, 61., 1999, Ithaca. Proceedings... Ithaca: Cornell University, 1999. p. 176185.

YÃNÉZ, E. A.; RESENDE, K. T.; FERREIRA, A. C. D.; PEREIRA FILHO, J. M.; SILVA SOBRINHO, A. G.; TEIXEIRA, I. A. M. A.; MEDEIROS, A. N. Restrição alimentar em caprinos: rendimento, cortes comerciais e composição da carcaça. Revista Brasileira de Zootecnia, Viçosa, MG, v. 35, n. 5, p. 2093-2100, 2006.

ZAPATA, J. F. F.; SEABRA, L. M. J.; NOGUEIRA, C. M.; BARROS, N. Estudo da qualidade da carne ovina do Nordeste brasileiro: propriedades físicas e sensoriais. Ciência e Tecnologia de Alimentos, Campinas, v. 20, n. 2, p. 274-277, 2000. 
